\title{
An experiment on thermal modelling of the Paleoproterozoic Fedorova layered intrusion, Kola Region, Russia: implications for the origin of contact-style PGE mineralisation
}

\author{
N. Yu. Groshev ${ }^{1 *}$, D. G. Stepenshchikov ${ }^{1}$ and B. T. Karykowski ${ }^{2}$ \\ ${ }^{1}$ Geological Institute, Kola Science Centre, Russian Academy of Sciences, 184209 Apatity, Russia \\ ${ }^{2}$ Fugro Germany Land GmbH, Resource Consulting, 12555 Berlin, Germany \\ *Corresponding author e-mail: nikolaygroshev@gmail.com
}

\begin{abstract}
Summary This contribution presents the results of thermal modelling of the Paleoproterozoic Fedorova intrusion located in the central part of the Kola Peninsula, NW Russia. The intrusion hosts a large contact-style platinum-group elements (PGE) deposit in its basal 300-m-thick unit (Fedorova Tundra). This basal unit is composed of varied-textured gabbronorite and is believed to be an additional injection of sulphide-saturated magma, representing a second intrusive phase. The irregular distribution of sulphides across the entire basal unit and the absence of sulphide liquid migration into the underlying basement rocks suggest that this second injection exploited the cooled down contact between the first intrusive phase and the basement. The hiatus between the first and the second intrusive event allowed for some cooling of the former, however, the duration of the hiatus remains unknown. Assuming an average geothermal gradient of $30^{\circ} \mathrm{C} / \mathrm{km}$ and a basement temperature of approx. $400^{\circ} \mathrm{C}$ due to preheating, thermal modelling indicates that the hiatus may have lasted for some 600-700 thousand years. These results are in agreement with a classic contact-style PGE mineralisation model for Fedorova Tundra and suggest an out-of-sequence formation of the layered succession.
\end{abstract}

\section{Introduction}

A critical factor in the formation of contact-style low-sulphide platinum group elements (PGE) mineralisation in layered mafic-ultramafic intrusions is the preheating of host rocks due to magmatic activity, preceding the emplacement of sulphide-saturated magma (Karykowski et al. 2018). Preheating of the basement to $400{ }^{\circ} \mathrm{C}$ by the intrusion of, for example, a series of dikes or sills that precede the main intrusion, creates conditions for the effective accumulation of sulphide droplets at the bottom of the magma chamber as well as for the percolation of sulphide droplets into the partially molten basement rocks. The Paleoproterozoic Portimo and Monchegorsk layered complexes on the Fennoscandian Shield are typical examples of intrusions where this factor played a crucial role (Iljina 1994; Karykowski et al. 2018).

The Fedorova intrusion represents the western block of the Paleoproterozoic FedorovaPana Complex located in the central part of the Kola Peninsula, NW Russia. The intrusion forms a 4-km-thick lens-like body that is steeply dipping to the southwest (Fig. 1a). Three zones are distinguished in the sequence of the Fedorova intrusion (from the bottom upwards): a NoriteGabbronorite Zone (or 'basal unit'), a Leucogabbro-Gabbronorite Zone, and a Leucogabbro Zone (Staritsina 1978). It is suggested that the Leucogabbro-Gabbronorite and the Leucogabbro zones comprise an early magmatic phase (2526-2515 Ma) with reef-style PGE mineralization, whereas the contact-style PGE mineralisation-hosting basal unit belongs to a later intrusive phase (2493-2485 Ma) (Schissel et al. 2002; Groshev et al. 2009; Groshev et al. 2019). The $300-\mathrm{m}$-thick basal unit is composed of varied-textured melanorite and gabbronorite containing abundant orthopyroxenitic autoliths and irregular patches of disseminated sulphide enriched in PGE (2-5 vol. \%) (Fig. 1, b). Evenly disseminated sulphide accumulations (20-30 vol. \%) are generally rare, whereas massive sulphides are absent. The PGE mineralisation is only hosted 
by the basal unit of the intrusion, showing no evidence for sulphide liquid percolation into the basement rocks. These sulphides form the Fedorova Tundra deposit with a total resources of more than $400 \mathrm{t}$ of PGE (Rasilainen et al. 2010).

(a)

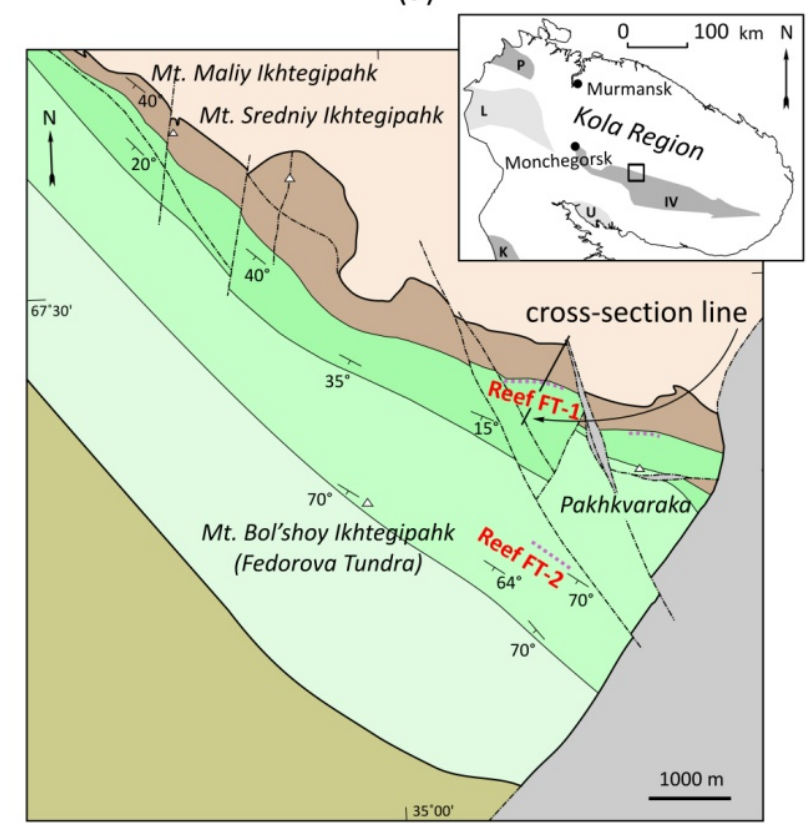

(b)

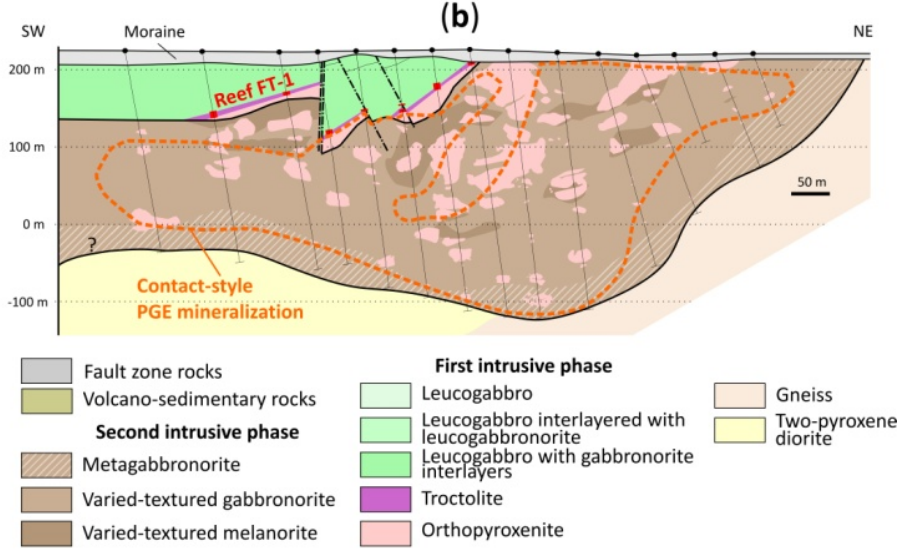

Figure 1. Simplified geologic map of the Fedorova Tundra intrusion (a) and schematic geologic cross section through the deposit (b). Purple dotted lines show a position of PGE reefs (FT1 and FT-2) on the map; red rectangles on the cross section indicate mineralized intervals of the FT-1 Reef. Proterozoic structures of the predominantly Archean Kola Region (inset): Imandra-Varzuga (IV), Kuolajarvi (K), and Pechenga (P) paleorift structures; Lapland (L) and Umba (U) granulite belts. Modified after (Groshev et al. 2019).

It is believed that the first intrusive phase of the Fedorova intrusion preheated the basement before the second phase intruded along the lower contact of the first intrusive phase (Fig. 1). A thermal contact aureole of the first phase reaches several hundred meters as evidenced by partially molten two-pyroxene diorites observed in some drill holes (Groshev et al. 2009). In spite of this the second intrusive phase does not practically show features of sulphide accumulation within the basal unit or sulphide percolation into the basement rocks. Consequently the time gap between the intrusive phases was long enough for cooling of the basement below $400{ }^{\circ} \mathrm{C}$ (temperature supporting sulphide migration and accumulation). The purpose of this study is to estimate the time gap between the two intrusive phases comprising the Fedorova intrusion using thermal modelling and to discuss the results in the context of the crystallization duration of layered intrusions as well as the formation of a contact-style PGE mineralisation. 


\section{Methods}

The cooling of the first intrusive phase of the Fedorova massif can be modelled by heat exchange between the magmatic succession with a temperature of $1200^{\circ} \mathrm{C}$, which has intruded the Archean basement at a depth of $5 \mathrm{~km}$ (Dubrovskiy and Rundkvist 2008). The thickness of the body is assumed to be $4 \mathrm{~km}$ (Groshev et al. 2019). Discretisation of the one-dimensional heat equation gives the following recurrence formula:

$$
T_{i}^{n+1}=T_{i}^{n}+k \Delta t\left(\frac{T_{i+1}^{n}-2 T_{i}^{n}+T_{i-1}^{n}}{(\Delta x)^{2}}\right),
$$

where $k$ - thermal diffusivity $\left(k=2 \cdot 10^{-6} \mathrm{~m}^{2} \mathrm{~s}^{-1}\right)$, and $T_{i}^{n}$ - temperature at a depth of $i \cdot \Delta x \mathrm{~m}$ in $n \cdot \Delta t$ years. A detailed derivation of the equation is given in (Karykowski et al. 2018). To eliminate boundary effects, the depth of modelling was increased to $20 \mathrm{~km}$. The thermal modelling was carried out using a FPC-based software (Stepenshchikov and Groshev 2019). Intrusive bodies are defined by four parameters: the boundary of the roof (m), thickness (m), temperature $\left({ }^{\circ} \mathrm{C}\right)$ and the point in time of intrusion (years).

\section{Thermal modelling results}

The simulation shows that the emplacement of the Fedorova first phase will lead to a significant heating of the underlying rocks (Fig. 2 a-c; Table 1). The partial melting temperature of the basement $\left(\approx 700{ }^{\circ} \mathrm{C}\right)$ will be reached approx. $250 \mathrm{~m}$ away from the lower intrusion contact after some 25 thousand years (Fig. 2 c, blue circle). This is in agreement with the thickness of twopyroxene diorite below the intrusion (Fig. $1 \mathrm{~b}$ ).
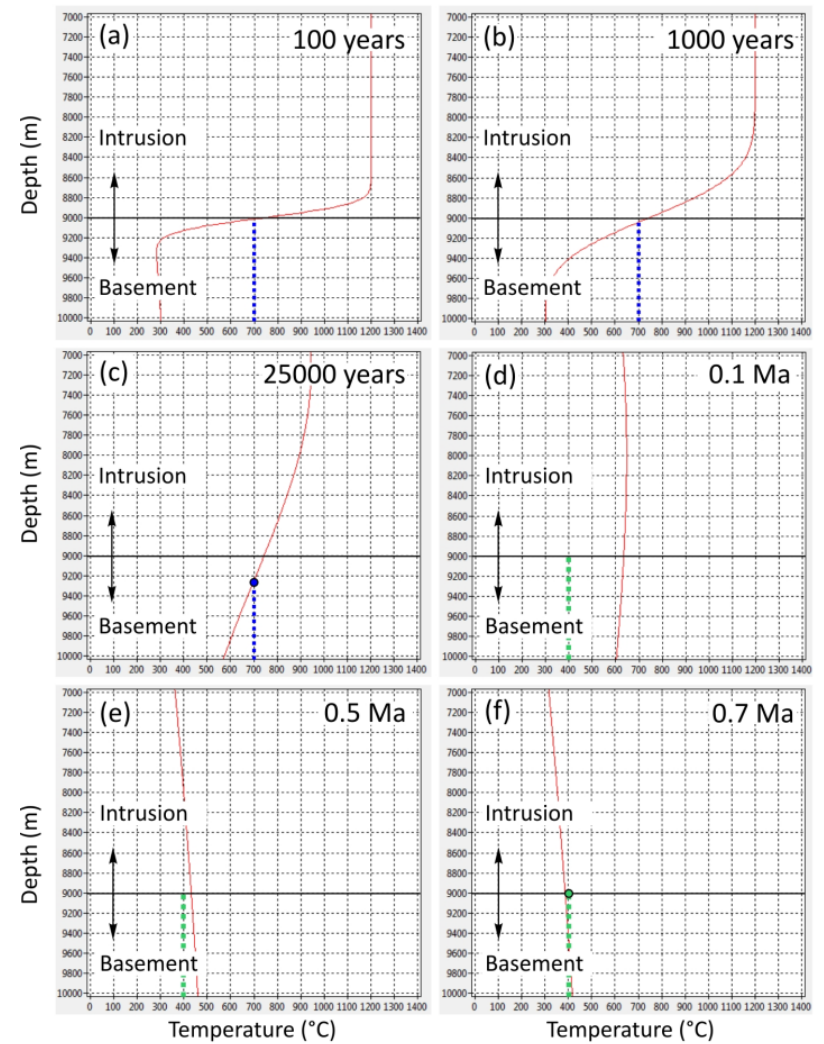

Figure 2. Temperature-depth graphs showing changes in temperature (red line) near the lower contact of the first intrusive phase of the Fedorova intrusion for different time moments $(\mathrm{a}-\mathrm{f})$. Note that an intrusion of the second phase could occur only after a contact cooling to $400{ }^{\circ} \mathrm{C}$ (green circle).

Since the magma of the second intrusive phase was sulphide-saturated, as a result of its emplacement in the preheated by the first phase contact with the basement the sulphides would have been concentrated near the bottom of the intrusion forming sulphide-rich layers and locally 
percolating into the Archean gneissic basement. Fig. $1 \mathrm{~b}$ shows that sulphides distributed unevenly and the migration of sulphide liquid is not observed at the Fedorova Tundra deposit. Consequently, the basal unit consisting of varied-textured gabbronorite that postdate the first intrusive phase were emplaced after the temperature at the lower contact of the first phase reached less than $400{ }^{\circ} \mathrm{C}$. Under these boundary conditions, the minimum time separating the different intrusive phases is some 600-700 thousand years, as can be seen in Fig. 2 e- $\mathrm{f}$ (green circle) and Table 1.

Table 1. Thermal modelling results for the first phase of the Fedorova intrusion.

\begin{tabular}{lccccc}
\hline \multirow{2}{*}{ (years) } & \multicolumn{2}{c}{ Temperature, $\mathrm{T}\left({ }^{\circ} \mathrm{C}\right)$} & \multirow{2}{*}{$\mathrm{t}$ (years) } & \multicolumn{2}{c}{ Temperature, $\mathrm{T}\left({ }^{\circ} \mathrm{C}\right)$} \\
$\mathrm{d}=5 \mathrm{~km}$ & $\mathrm{~d}=9 \mathrm{~km}$ & & $\mathrm{~d}=9 \mathrm{~km}$ \\
\hline 1 & 839 & 880 & 400000 & 306 & 462 \\
10 & 732 & 787 & 500000 & 276 & 431 \\
100 & 692 & 753 & 600000 & 254 & 407 \\
1000 & 677 & 744 & 700000 & 236 & 386 \\
10000 & 663 & 750 & 800000 & 223 & 369 \\
100000 & 517 & 635 & 900000 & 211 & 355 \\
200000 & 415 & 551 & 1000000 & 202 & 342 \\
300000 & 350 & 500 & - & - & -
\end{tabular}

\section{Discussion}

\subsection{Duration of the Fedorova intrusion crystallization}

The example of the Fedorova intrusion shows that the duration of crystallization under opensystem conditions can be hundreds of thousands of years (Fig. 2). At the same time, the latest data on systematic isotope dating of open-system layered intrusions, show that the duration of their crystallization ranges from 1 to $3 \mathrm{Ma}$ with an error of individual age determinations of up to 0.26 Ma modulo (Scoates and Wall 2015; Zeh et al. 2015; Wall et al. 2018). In this regard, it is worth noting that the currently available geochronological data on the Fedorova intrusion suggest a duration of crystallisation spanning some $40 \mathrm{Ma}$ (Groshev et al. 2009), which appears to be greatly overestimated due to the likely inclusion of secondary zircon in the calculation of $\mathrm{U}-\mathrm{Pb}$ ages (Groshev and Karykowski 2019).

Thus, the Fedorova Tundra deposit most likely represents a separate 'out-of-sequence'type of contact-style PGE mineralization. The advancement of the isotope age determination on the intrusive phases of the Fedorova intrusion is possibly one of the most important unresolved problems in the petrology of layered intrusions on the Fennoscandian Shield.

\subsection{Similar contact-style PGE mineralization in other layered intrusions}

The presence or absence of sulphide liquid migration from the basal mineralised zones into the basement rocks is an important genetic feature of contact-style PGE deposits, revealing their thermal history. Except the Fedorova intrusion it can be shown by thermal modeling for the Nyud-Poaz massif (Monchegorsk Complex), which has two ore-bearing intrusive phases both containing disseminated sulfides, extending beyond the intrusion in the basement (Karykowski et al. 2018; Groshev and Pripachkin 2018). An additional phase (Gabbro-10), emplaced along the basal contact of the Nyud-Poaz intrusion hosts PGE mineralisation that percolates into the Archean basement for $30 \mathrm{~m}$ Consequently, the additional injection of sulphide-saturated magma occurred at a time when the basal contact of the Nyud-Poaz massif was characterised 
by elevated temperatures. The time gap between these two phases, according to the thermal modelling of the Nyud-Poaz massif, is no more than 150 thousand years. The accuracy of isotope dating cannot resolve such small time differences at the moment (Scoates and Wall 2015). This is also shown by the isotope dating of the Gabbro-10 intrusion whose age coincides with the age of the Nyud-Poaz massif within the error limits (Amelin et al. 1995; Groshev et al. 2018).

The South Sopcha intrusion of the Monchegorsk Complex is another example of contact-style PGE mineralisation that was likely formed out-of-sequence (Chashchin and Mitrofanov 2015; Pripachkin et al. 2015). The South Sopcha intrusion has an orthopyroxenitic lower unit, which is extensively intruded and brecciated by sill-like gabbro-pegmatites and coarse-grained gabbronorites containing PGE-rich disseminated sulphide. The issues of sulphide migration from the gabbronorites into the basement rocks as well as the duration of the South Sopcha crystallisation are to be solved in future research.

\section{Acknowledgements}

The research was supported by the Ministry of Science and Higher Education of the Russian Federation (project 0226-2019-0053).

\section{References:}

Amelin YV, Heaman LM, Semenov VS (1995) U-Pb geochronology of layered mafic intrusions in the eastern Baltic Shield: implications for the timing and duration of Paleoproterozoic continental rifting. Precambrian Res 75:31-46. doi: 10.1016/0301-9268(95)00015-W

Chashchin VV, Mitrofanov FP (2015) The Paleoproterozoic Imandra-Varzuga Rifting Structure (Kola Peninsula): Intrusive Magmatism and Minerageny. Geodin i Tektonofiz 5:231-256

Dubrovskiy MI, Rundkvist TV (2008) Petrology of the Early Proterozoic platinum-bearing Fedorova tundras massif (Kola Peninsula). Zap RMO CXXXVII:20-33

Groshev NY, Karykowski BT (2019) The Main Anorthosite Layer of the West-Pana Intrusion, Kola Region: Geology and U-Pb Age Dating. Minerals 9:71. doi: 10.3390/min9020071

Groshev NY, Nitkina EA, Mitrofanov FP (2009) Two-phase mechanism of the formation of platinum-metal basites of the Fedorova Tundra intrusion on the Kola Peninsula: New data on geology and isotope geochronology. Dokl Earth Sci 427:1012-1016. doi: 10.1134/S1028334X09060270

Groshev NY, Pripachkin PV, Karykowski BT, et al (2018) Genesis of a Magnetite Layer in the Gabbro-10 Intrusion, Monchegorsk Complex, Kola Region: U-Pb SHRIMP-II Dating of Metadiorites. Geol Ore Depos 60:486496. doi: $10.1134 / \mathrm{s} 1075701518060028$

Groshev NY, Rundkvist T V, Karykowski BT, et al (2019) Low-Sulfide Platinum-Palladium Deposits of the Paleoproterozoic Fedorova-Pana Layered Complex, Kola Region, Russia. Minerals 9:764 doi.org/10.3390/min9120764

Iljina M (1994) The Portimo layered igneous complex: with emphasis on diverse sulphide and platinum-group element deposits. University of Oulu Oulu, Finland

Karykowski BT, Maier WD, Groshev NY, et al (2018) Critical controls on the formation of contact-style PGE-Ni$\mathrm{Cu}$ mineralization: Evidence from the paleoproterozoic Monchegorsk Complex, Kola Region, Russia. Econ Geol 113:911-935. doi: 10.5382/econgeo.2018.4576

Pripachkin PV, Rundkvist TV, Miroshnikova YA, et al (2015) Geological structure and ore mineralization of the South Sopchinsky and Gabbro-10 massifs and the Moroshkovoe Lake target, Monchegorsk area, Kola Peninsula, Russia. Miner Depos 973-992. doi: 10.1007/s00126-015-0605-0

Rasilainen K, Eilu P, Halkoaho T, et al (2010) Quantitative mineral resource assessment of undiscovered PGE resources in Finland. Ore Geol Rev 38:270-287. doi: 10.1016/j.oregeorev.2010.05.001

Schissel D, Tsvetkov AA, Mitrofanov FP, Korchagin AU (2002) Basal Platinum-Group Element Mineralization in the Federov Pansky Layered Mafic Intrusion, Kola Peninsula, Russia. Econ Geol 97:1657-1677. doi: 10.2113/gsecongeo.97.8.1657

Scoates JS, Wall CJ (2015) Geochronology of Layered Intrusions. In: Charlier B (ed) Layered Intrusions. Springer Netherlands, Dordrecht, pp 3-74

Staritsina GN (1978) Fedorova Tundra massif of basic-ultrabasic rocks. In: Issues of geology and mineralogy, Kola Peninsula. Apatity, Kola Branch AS USSR, pp 50-91 
Stepenshchikov DG, Groshev NY (2019) The application software for thermal modeling of intrusions. Tr FNS 16: $565-567$

Wall CJ, Scoates JS, Weis D, et al (2018) The Stillwater Complex: Integrating Zircon Geochronological and Geochemical Constraints on the Age, Emplacement History and Crystallization of a Large, Open-System Layered Intrusion. J Petrol 59:153-190

Zeh A, Ovtcharova M, Wilson AH, Schaltegger U (2015) The Bushveld Complex was emplaced and cooled in less than one million years - results of zirconology, and geotectonic implications. Earth Planet Sci Lett 418:103114. doi: 10.1016/j.epsl.2015.02.035 